\title{
Ecological Degradation of the Yangtze and Nile Delta-Estuaries in Response to Dam Construction with Special Reference to Monsoonal and Arid Climate Settings
}

\author{
Zhongyuan Chen ${ }^{1, *}$, Hao $\mathrm{Xu}^{2}(\mathbb{D})$ and Yanna Wang ${ }^{1}$ \\ 1 State Key Laboratory of Estuarine and Coastal Research, East China Normal University, \\ Shanghai 200062, China; ynwang@sklec.ecnu.edu.cn \\ 2 Department of Geography and Spatial Information Techniques, Ningbo University, Ningbo 315211, China; \\ xuhao@nbu.edu.cn \\ * Correspondence: z.chen@sklec.ecnu.edu.cn
}

Citation: Chen, Z.; Xu, H.; Wang, Y. Ecological Degradation of the Yangtze and Nile Delta-Estuaries in Response to Dam Construction with Special Reference to Monsoonal and Arid Climate Settings. Water 2021, 13, 1145 https://doi.org/10.3390/w13091145

Academic Editor: Bommanna Krishnappan

Received: 18 March 2021

Accepted: 19 April 2021

Published: 21 April 2021

Publisher's Note: MDPI stays neutral with regard to jurisdictional claims in published maps and institutional affiliations.

Copyright: () 2021 by the authors. Licensee MDPI, Basel, Switzerland. This article is an open access article distributed under the terms and conditions of the Creative Commons Attribution (CC BY) license (https:// creativecommons.org/licenses/by/ $4.0 /)$.

\begin{abstract}
This study reviews the monsoonal Yangtze and the arid Nile deltas with the objective of understanding how the process-response between river-basin modifications and delta-estuary ecological degradation are interrelated under contrasting hydroclimate dynamics. Our analysis shows that the Yangtze River had a long-term stepwise reduction in sediment and silicate fluxes to estuary due to dam construction since the 1960s, especially after the Three Gorges Dam (TGD) closed in 2003. By contrast, the Nile had a drastic reduction of sediment, freshwater, and silicate fluxes immediately after the construction of the Aswan High Dam (AHD) in 1964. Seasonal rainfall in the mid-lower Yangtze basin (below TGD) complemented riverine materials to its estuary, but little was available to the Nile coast below the AHD in the hyper-arid climate setting. Nitrogen (N) and phosphate (P) fluxes in both river basins have increased because of the overuse of $\mathrm{N}$ - and P-fertilizer, land-use changes, urbanization, and industrialization. Nutrient ratios (N:P:Si) in both delta-estuaries was greatly altered, i.e., Yangtze case: 75:1:946 (1960s-1970s), 86:1:272 (1980s-1990s) and 102:1:75 (2000s-2010s); and Nile case: 6:1:32 (1960s-1970s), 8:1:9 (1980s-1990s), and 45:1:22 (2013), in the context of the optimum of Redfield ratio (N:P:Si = 16:1:16). This led to an ecological regime shift evidenced by a long-term change in phytoplankton communities in the Yangtze estuary, where silicious algae tended to lose dominance since the end of the 1990s, when more toxic dinoflagellates began to emerge. In the Nile estuary, such a regime shift was indicated by the post-dam dramatic reduction in zooplankton standing crop and fish landings until the early 2000s when biological recovery occurred due to nutrient inputs from anthropogenic sources. Although the Yangtze had higher human impacts than the Nile in terms of population, industrialization, and fertilizer application, $\mathrm{N}$ concentrations in the Nile estuarine waters surpassed the Yangtze in recent decades. However, eutrophication in the Yangtze estuary is much more intensive than in the Nile, leading to the likelihood of its estuarine water becoming more acidic than ever before. Therefore, ecological degradation in both delta-estuaries does not follow a linear trajectory, due not only to different climate dynamics but also to human forcings. The comparative insights of this study should be incorporated into future integrated coastal management of these two important systems.
\end{abstract}

Keywords: altered nutrient ratio; riverine flux; bio-transformation; river-basin-scale; post-dam consequences

\section{Introduction}

River basins have been extensively modified by intensive human activities over the last half-century, causing severe environmental degradation globally in delta-estuary systems [1,2]. Overuse of bio-chemical fertilizers, water transfers, urbanization, deforestation, and industrialization in river basins have increasingly degraded healthy habitats on which human society depends. Dam construction in river basins has considerably altered the 
delivery of riverine materials to the sea, mainly sediment, water, nitrogen $(\mathrm{N})$, phosphate $(\mathrm{P})$, and silicate $(\mathrm{Si})$. As a result, the health of delta-estuarine systems remains at risk $[1,3]$.

Using China's Yangtze delta and Egypt's Nile delta as a comparative example, the objective of this paper was to highlight how riverine delivery processes and related mechanisms undergo change and how delta-estuarine responses occur ecologically, given their contrasting geographic setting in terms of climate change and anthropogenic intervention (hereafter dual forcings). Although both the Yangtze and Nile delta-estuaries have some similarities in process-response of environmental degradation, there are also differences that inform how human impacts affect these two important deltaic systems.

The human population is a key forcing in modifying the land surface of both river basins. There were about 200 million people in the Yangtze basin in the 1960s and, since then, it has increased to about 400 million (http: / / www.stats.gov.cn/tjsj/ndsj/ (accessed on 2 March 2021)) [4], of which about 70 million now live in the Yangtze Delta. The population of the Nile delta was about 43 million in the 1980s, and it increased to nearly 100 million by 2019, almost all of whom live in the delta (https: / / databank.worldbank.org/home.aspx (accessed on 2 March 2021)) [5].

The Yangtze River, including its delta, is located in the monsoonal climate zone of East Asia, while the Nile delta is arid in NW-Africa, although its upper basin is also highly monsoonal. Geologically, the Yangtze is composed of many large-scale sub-basins (Figure 1A) throughout the entire basin, but the Nile has fewer tributaries, mostly in the upper basin (Figure 1B). During past decades, numerous dams have been built in the Yangtze basin, including the Three Gorges Dam (TGD, closed in 2003, and about $1800 \mathrm{~km}$ from the coast). In the Nile basin, there is only one major dam, the Aswan High Dam (AHD) dam on the mainstream, which was closed in 1964 and about $1000 \mathrm{~km}$ from the coast. Understanding the position of the dam sites in the river basin is important in studying riverine material transport (discussion given below).

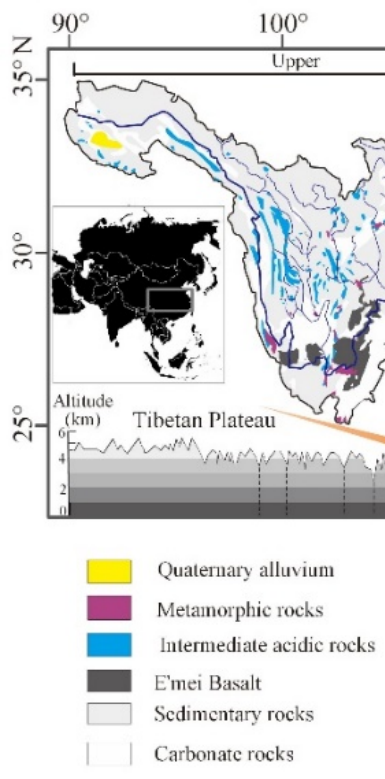

Lithologic legend in A

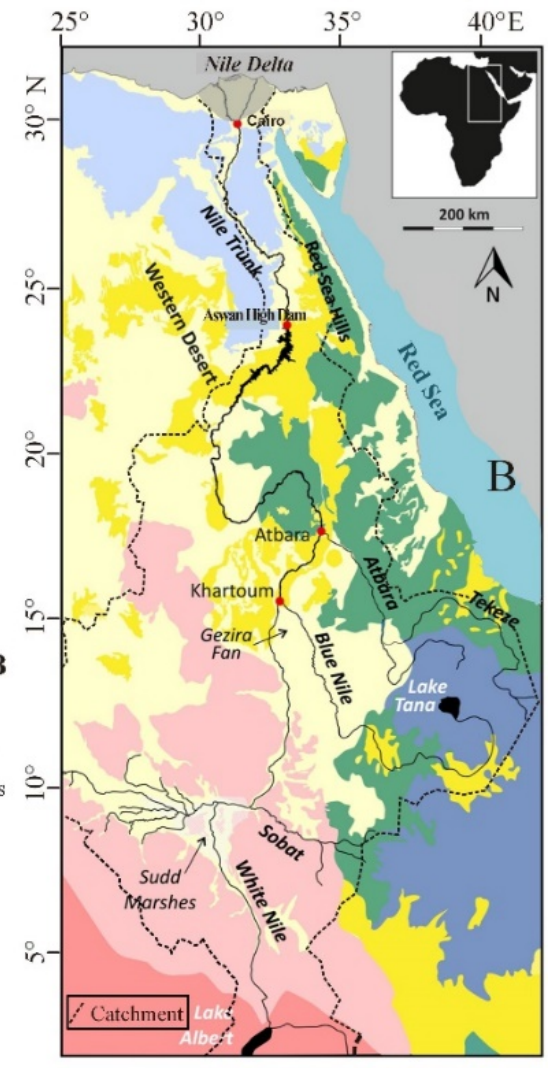

Figure 1. (A) The Yangtze River basin, showing the location of the Three Gorges Dam (TGD) and Datong hydro-gauging station. (B) The Nile River basin, showing the location of the Aswan High Dam (AHD). The lithology of both river basins is modified from $[6,7]$. 
Inevitably, dam construction has changed the river water from high to low turbidity. $\mathrm{N}$ - and P-fluxes have increased significantly in both systems, but Si flux has decreased. This had led to deleterious ecological responses in both systems. The goal of this review was to discuss the scientific understanding of how these changes have impacted these two systems in order to provide insights for their management.

\section{Summary of Findings}

We synthesized a 60-year hydro-ecological database in the light of an extensive literature review of published papers and technical reports from local governments (Figures 2 and 3).

\section{Yangtze River}
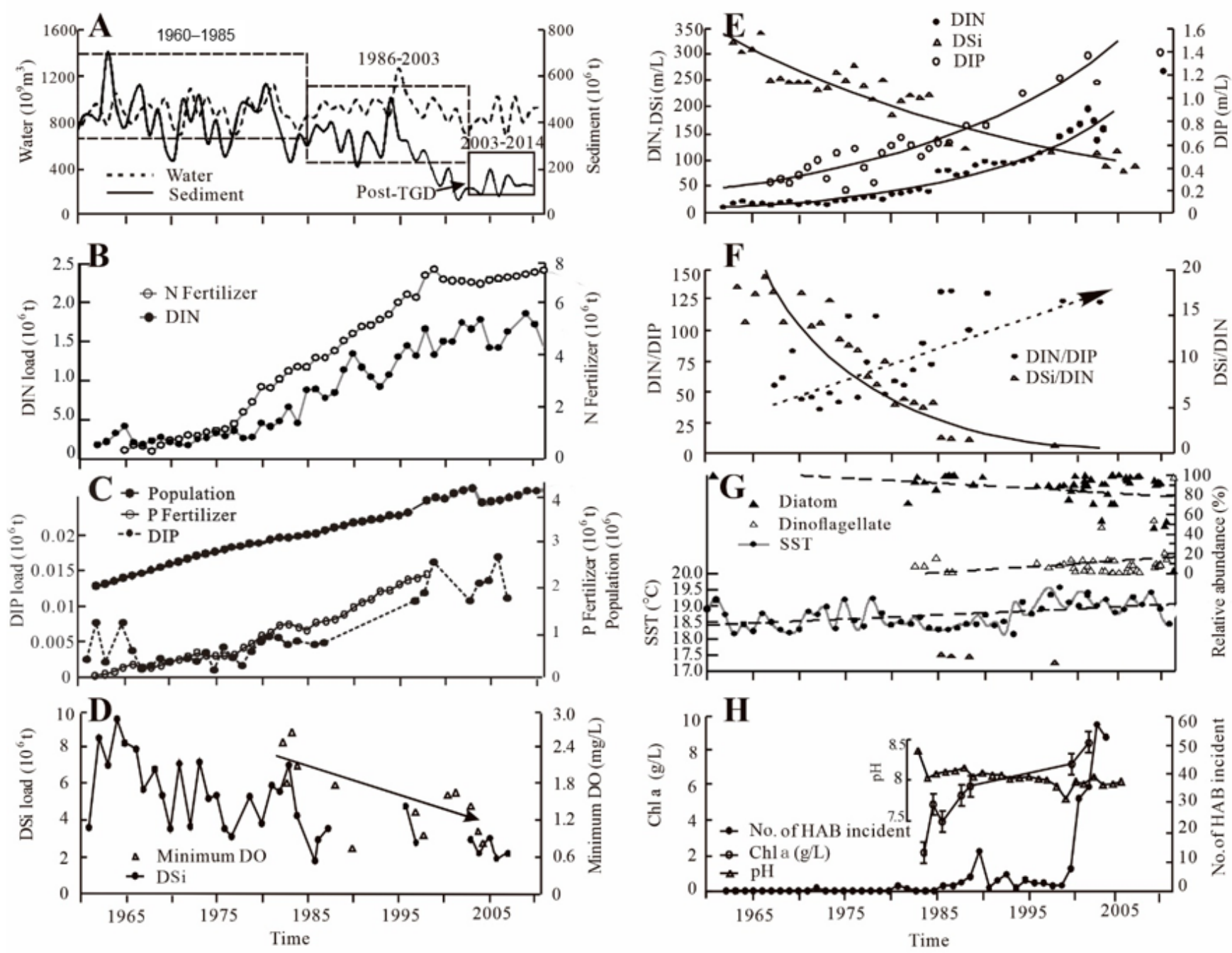

Figure 2. Long-term variations of both riverine materials transport to the Yangtze delta-estuary and estuarine ecological components. (A) Sediment and freshwater (recorded at Datong hydro-gauging station, Figure 1A; CWRCMWR, 1960-2016); (B-F) Nutrients (CWRCMWR, 1960-2016). Fertilizer and population in (B,C) sourced from http://www.stats.gov.cn/tjsj/ ndsj/ (accessed on 2 March 2021) [4]; (G) Diatom and relative dinoflagellate abundance of the Yangtze estuary [7]; (H) Chla [8]; HAB (http:/ / www.mnr.gov.cn/sj/sjfw/hy /gbgg/zghyhjzlgb / (accessed on 2 March 2021) [9] and Tang (2009) [10]; pH [11]; DIN: Dissolved inorganic nitrogen; DIP: Dissolved inorganic phosphorus; DSi: Dissolved silicate; SST: Sea surface temperature; HAB: Harmful algae bloom, Chl a: Chlorophyll a; DO: Dissolved oxygen (abbreviations also used in Figure 3). 


\section{Nile River}
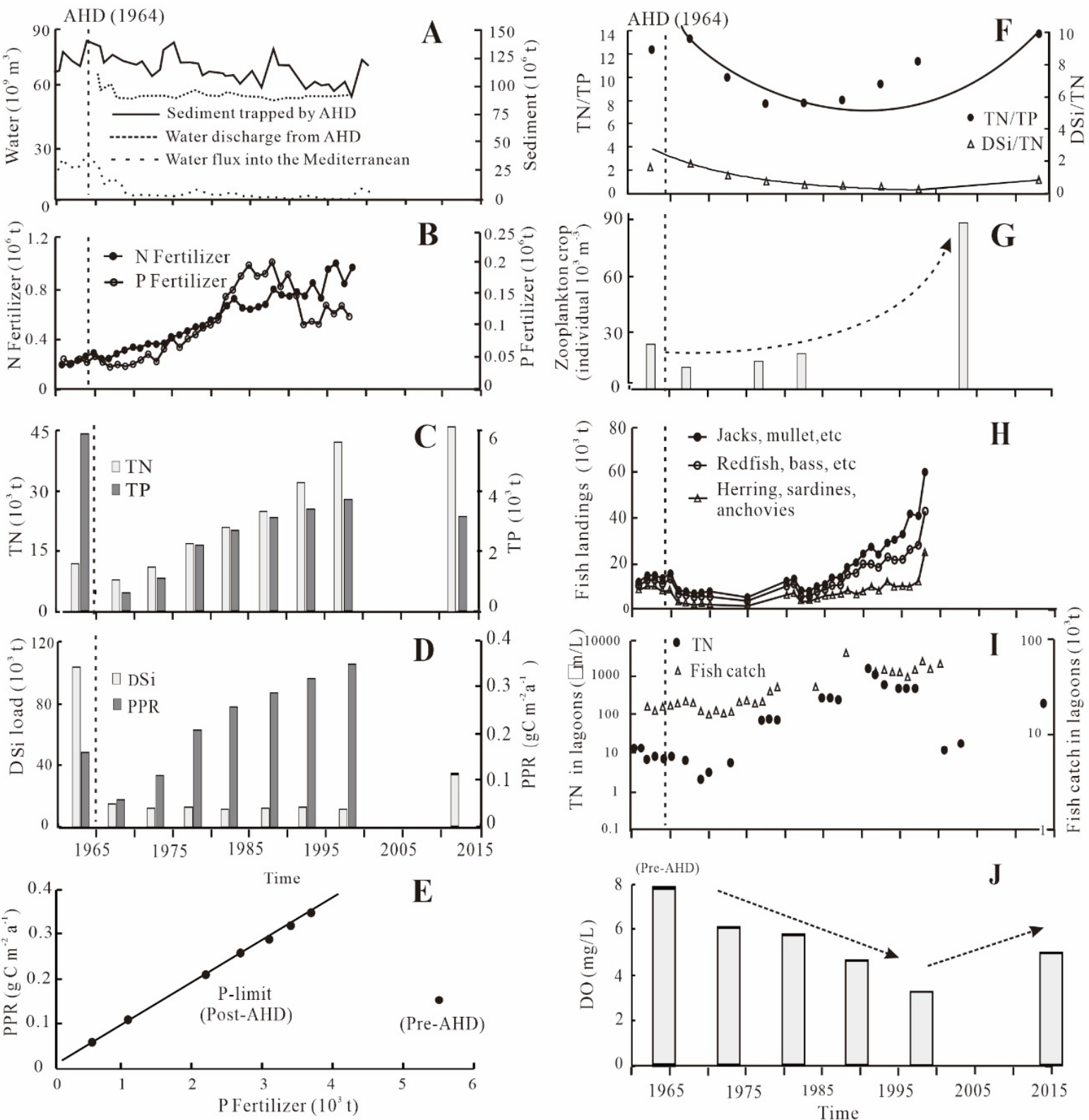

Figure 3. Long-term variations of both Nile River riverine materials transport to the delta-estuary and estuarine ecological components. (A) Sediment and freshwater [12]; (B) Fertilizer [13]; (C) TN and TP loads [14,15]; (D) DSi load and PPR [14,15]; (E) PPR and P-fertilizer [13,14]; (F) N/P and DSi/TN [14,15]; (G) Zooplankton crop in Abu-Qir Bay [16]; (H) Fish landing [13]; (I) Inorganic nitrogen concentrations and the fish catch of the 4 Nile lagoons [17,18]; (J) Dissolved oxygen (DO) concentrations in the Maryut Lagoon [18,19]; TN: total nitrogen; TP: total phosphorus; PPR: primary production rate.

\subsection{Altered Sediment and Water Transport}

Dams have dramatically reduced sediment transport to both delta-estuaries over the past 60 years. Yangtze sediment has decreased from $\sim 480 \mathrm{mt} \mathrm{a}^{-1}$ in the 1960 s to $350 \mathrm{mt} \mathrm{a}^{-1}$ in the 1990s and to $<120 \mathrm{mt} \mathrm{a}^{-1}$ after TGD closed in 2003 (Figure 2A) (CWRCMWR, 1960-2016; Figure 1A). Data for this study came from the Datong hydro-gauging station, the last station before the river enters the coast (Figure 1). However, the dams did not reduce the annual freshwater discharge of the Yangtze to sea because of the East Asian monsoon that has yielded relatively constant rainfall, leading to an average annual discharge of ca. $960 \times 10^{9} \mathrm{~m}^{3}$ flowing to the coast (Figure $2 \mathrm{~A}$ ). 
However, the Yangtze River is seasonal with its seasonally shifting rain zone [20,21]. On average, about 50\% of the rain falls in the mid-lower basin (below TGD) during late March-July, and another half falls in the upper basin during August-October [21]. The rainfall of March-July intensifies post-TGD river-channel erosion through less-turbid freshwater discharging downstream. This provides a new sediment source for the deltaestuary [21,22]. On the other hand, the operation mode of TGD, i.e., lowering the water level before flooding (June-October) and a rising water level after flooding (NovemberMay), has changed the seasonal discharge at the river mouth. Peak flooding in the summer has reduced, and the lower flow of winter has increased.

This is certainly not the case for the Nile. The AHD has greatly reduced both freshwater and sediment discharge to the Mediterranean coast over the past 60 years. Before the AHD, the Nile transported ca. $150 \mathrm{mt} \mathrm{a}^{-1}$ of sediment to the coast, but most sediment is now trapped in the reservoir (Figure 3A) [12]. Although about $1 / 6$ of the sediment can still be released from the dam, little reaches the river mouth (Figure $3 \mathrm{~A}$ ) as a result of the modified dynamics of water flow. After 1964, about $60 \times 10^{9} \mathrm{~m}^{3} \mathrm{a}^{-1}$ freshwater was discharged downstream; however, $>95 \%$ of this is barraged for agricultural irrigation, in addition to higher evaporation on the course of transport under hyper-arid climate conditions [23].

\subsection{Overused Fertilizers and Enriched Nutrients}

Fertilizer use in both river basins has dramatically increased over the past decades. $\mathrm{N}$-fertilizer application in the Yangtze basin was $1-2 \times 10^{6} \mathrm{t} \mathrm{a}^{-1}$ from the 1960s to the 1970s and increased to about 7-8 $\times 10^{6} \mathrm{t} \mathrm{a}^{-1}$, recently (Figure 2B) (http: / / www.stats.gov.cn/tjsj/ ndsj / (accessed on 2 March 2021)) [4]. P-fertilizer use increased from 0.2-0.5 $\times 10^{6} \mathrm{t} \mathrm{a}^{-1}$ during the $1960 \mathrm{~s}-1970 \mathrm{~s}$ to $2.5 \times 10^{6} \mathrm{t} \mathrm{a}^{-1}$ at the end of the 1990s (Figure 2C). Both N- and P-fertilizers use was stable after 2000 due to national policies [24].

The overuse of fertilizers is directly related to dissolved inorganic nitrogen (DIN) and dissolved inorganic phosphorus (DIP) transport in the Yangtze River (Figure 2B,C). Recently, DIN and NIP are increasing from the urbanization of the river basin [24].

$\mathrm{N}$ - and P-fertilizer use also increased in the Nile basin. N-fertilizer increased from 0.2 to $0.8 \times 10^{6} \mathrm{t} \mathrm{a}^{-1}$ in the $1960 \mathrm{~s}$ to the $1990 \mathrm{~s}$ (Figure 3B) ([13]; measured at Cairo), and P-fertilizer went up from 0.05 to $0.2 \times 10^{6} \mathrm{t} \mathrm{a}^{-1}$ from the 1960s to the 1980s, followed by a decline after 1990 due to restrictions on $\mathrm{P}$ use in fertilizers and detergents. Thus, TN and TP increased in Nile estuarine waters (Figure 3C) [14,15], but TP had a different pattern. There was high TP discharge $\left(6 \times 10^{3} \mathrm{t} \mathrm{a}^{-1}\right)$ before the AHD, which decreased to $0.8 \times 10^{3} \mathrm{t} \mathrm{a}^{-1}$ immediately after dam construction. It then increased to about $3.6 \times 10^{3} \mathrm{t} \mathrm{a}^{-1}$ (Figure 3C) but has not returned to the level before damming. This hints that $\mathrm{P}$ is mostly sourced from the upper Nile basin to have been accumulated in the reservoir because of its particulate form. TN was not significantly affected by damming. It was about $12 \times 10^{3} \mathrm{t} \mathrm{a}^{-1}$ prior to the AHD, then followed by a rapid rise to $15-25 \times 10^{3} \mathrm{t} \mathrm{a}^{-1}$ from the 1970 s to the 1980s. $\mathrm{TN}$ increased to $45 \times 10^{3} \mathrm{t} \mathrm{a}^{-1}$ recently (Figure $3 \mathrm{C}$ ), perhaps relating to nitrogen-fixing algae in the impoundment. It is evident that there was $\mathrm{N}$-limitation in the Nile estuarine waters before the AHD, which has changed gradually to P-limitation afterward.

\subsection{Deficit Budget of Silicate}

Dissolved silicate (DSi) flux to coastal waters in both the Yangtze and the Nile estuaries has decreased considerably due to dam construction. There was a stepwise decline in the Yangtze from 8-4 × $10^{6} \mathrm{t} \mathrm{a}^{-1}$ from the 1960s to the 1980s, which was followed by a further decrease to about $2 \times 10^{6} \mathrm{t} \mathrm{a}^{-1}$ in the 2000s (Figure 2D) [25]. DSi declined rapidly in the Nile after the dam's closure in 1964 (Figure 3D) [14]. Pre-dam DSi was about $110 \times 10^{3} \mathrm{t} \mathrm{a}^{-1}$, which dropped quickly to $15 \times 10^{3} \mathrm{t} \mathrm{a}^{-1}$ after 1964 . DSi increased slightly to about $38 \times 10^{3} \mathrm{t} \mathrm{a}^{-1}$ in the 2010s.

DSi decline was related to the residence time of water in reservoirs. This would favor algae blooms in reservoirs, which sequester dissolved silicate in phytoplankton tests [26]. The extensive mid-lower Yangtze sub-basin can still provide substantial silicate 
via monsoon rainfall to the estuary after TGD construction, as evidenced by a stepwise decrease in annual fluxes, but this does not happen for the Nile. The AHD has exclusively blocked most silicate flux, and no more silicate sources are available below the AHD to supply to the delta-estuary under arid climate conditions.

\section{Estuarine Ecological Responses}

The estuarine ecological setting serves as a "sensitive-responder" to modifications in the drainage basins (Figure 2A-D and Figure 3A-D). Ecological responses in both the Yangtze and the Nile delta-estuaries are significant in the context of cross-cutting environmental forcings.

Although both delta-estuaries share some common processes and mechanisms, there are remarkable differences between the two systems. The "clear water" situation with extremely low suspended sediment concentrations in the Nile estuary after the AHD do not occur in the Yangtze because of monsoon rains leading to significant contributions from tributaries below the TGD [21]. In addition, strong seabed re-suspension prevails on the Yangtze coast throughout the year, which maintains turbid conditions [27], albeit not as much as the pre-dam stage.

These geographical conditions make the two delta-estuaries distinctive in the processresponse model described below.

\subsection{Altered Nutrient Balance}

The heavy use of commercial fertilizers in the Yangtze basin in the past decades has led directly to increasing DIN and DIP, while DSi has gradually declined by $40 \%$ in the estuarine waters (Figure 2B-E) $[7,26]$. The nutrient balance before damming has been dramatically altered (Figure 2E,F). Both DIN and DIP concentration have gone up, respectively, from 20 to $150 \mu \mathrm{m} \mathrm{L}^{-1}$ and 0.4 to $1.4 \mu \mathrm{m} \mathrm{L}^{-1}$, respectively, from the $1960 \mathrm{~s}$ to the 2010s, while DSi concentrations dropped from $350 \mu \mathrm{m} \mathrm{L}^{-1}$ in the 1960 s to $100 \mu \mathrm{m} \mathrm{L}^{-1}$ in the 2000s (Figure 2E).

As a result, the N:P:Si ratio in the Yangtze estuary has been modified from 75:1:946 in the 1960s-1970s to $86: 1: 272$ during the 1980 s to 1990 s, and then to $102: 1: 75$ by 2000 s-2010s (Figure 5 of [7]). In the context of the optimum Redfield ratio (N:P:Si $=16: 16: 1)$ in coastal water, it is evident that the rapidly increasing rate of DIN plays a key role in degrading estuarine water quality, although P-limitation exists and DSi has declined [7]. Consequently, the DSi/DIN ratio has decreased as the DIN/DIP has increased during the last half-century (Figure 2F). Undoubtedly, DIN has become excessive in the Yangtze estuarine water, being the key issue in environmental deterioration now and in the future [28].

The Nile estuarine water quality has also degraded due to changes in the transport of riverine materials to sea (Figure $3 \mathrm{~A}-\mathrm{D}$ ). Overuse of $\mathrm{N}$ - and P-fertilizer in the river basin, together with dramatically reduced DSi (Figure 3B-D) has changed nutrient ratios that favor eutrophication and the development of harmful algae blooms (HABs). The pre-dam (1964) N:P:Si was 5:1:20, to be changed to post-dam (1970) N:P:Si = 19:1:9 and (2013) 32:1:12 (data sourced from [14,15]. Post-dam P-limitation also existed before 2000 (Figure 3E) [14]. DSi/DIN has been kept at a minimal long-term level after the AHD, but TN/TP, after a reduction due to the AHD, has had a small rise in recent years (Figure 3F) [14,15]. The long-term alteration of nutrient ratios in both of the delta-estuaries has caused ecological issues, as discussed below.

\subsection{Eco-Biological Responses}

As a consequence of changes in riverine fluxes, the Yangtze estuarine environment has degraded severely. A long-term (interdecadal scale) change in phytoplankton communities is impacted by water pollution and sea-surface temperature warming $[7,29]$. The reduced silicate flux tends to lead to silicious communities that prevailed before the 1990s to lose dominance to dinoflagellates beginning in the 1990s [7,28,30] (Figure 2G). Skeletonema spp., the most common diatoms in the estuary, have lost about $50 \%$ of their abundance since the 
early 2000s $[7,30]$. Before this time, there were a few dominant diatom taxa, but by today more silicious species have emerged, along with many dinoflagellates species, which is mainly driven by the altered riverine nutrient ratios $[7,30]$.

The system response in the Nile estuarine zone was a reduction in the zooplankton standing crop of about $20 \times 10^{3}$ individuals $\mathrm{m}^{-3}$ after the closure of the AHD in 1964. By the early twenty-first century, zooplankton standing crop increased to $90 \times 10^{3}$ individuals $\mathrm{m}^{-3}$ (Figure 3G) [14,15]. Fish landings have also increased (Figure 3G,H) [13]. In general, these patterns are related to increased nutrient delivery to the estuary, although improved fishing technology was a factor (Figure 3I) [17,18].

The increases in nutrients enhanced primary production, such as phytoplankton development. With more food available, fisheries could recover. Fertilizer and sewage outfalls provide more than enough nutrients to offset those retained by the AHD (Figure 3C,D,F) [13].

\subsection{Oxygen Depletion and Decreased $p H$}

Water quality degradation is indicated by levels of Chlorophyll a in less-turbid estuarine waters due to low suspended sediment concentration (SSC) and high nutrient concentrations in relation to damming impact [31]. This causes blooms of non-silicious algae in the Yangtze estuary (Figure 2G), leading to low dissolved oxygen (DO) in the estuarine water column due to the decomposition of dead algal cells in the lower portion of the water column. The number of HAB increased by up to 10 times per year in the $1980 \mathrm{~s}$ and more than 50 times per year in the 2000s (Figure 2H) [28,32].

In response, hypoxia $\left(\mathrm{O}_{2}<2 \mathrm{mg} / \mathrm{L}\right)$ has appeared with increasing frequency in recent decades in Yangtze coastal waters [33]. Oxygen depletion causes a lower $\mathrm{pH}$. The average $\mathrm{pH}$ value in the Yangtze estuary has decreased from 8.2 to 7.9 from the early 1980s to 2006 (Figure 2H) [11], implying that the estuarine water is more acidic than ever before.

We have not found any historical $\mathrm{pH}$ value for the Nile coast, but oxygen depletion and hypoxia doubled in the 1980s-1990s period as compared to before the closure of the AHD (Figure 3J) [19]. It is most likely that lowered $\mathrm{pH}$ would also occur in the Nile estuary.

\section{What Can We Learn from This Comparative Study?}

The process-response of the Yangtze and Nile River delta-estuaries can provide environmental insights into the future study and coastal management.

First, we show the similarities and differences of processes-responses between the Yangtze and Nile basins, including deltas. Thus, although there are similarities in deltaic and river basin dynamics [1,3], each system is also unique in certain aspects due to climatic, geographic, and other factors. The monsoonal Yangtze, together with the mode of dam operation, has played key roles in modifying riverine material transport, characterized by the stepwise reduction in sediment silicate loads, but not the annual freshwater inflow. Substantial materials are derived from the mid-lower Yangtze sub-basin below the TGD due to seasonal rainfall patterns (Figure 2A,D). This contrasts with the lower Nile River (including the Nile delta), where the closure of the AHD resulted in dramatic reductions in freshwater, sediment, and silicate flux to the delta (Figure 3A,D). The arid climate setting has very little impact on material delivery to sea.

Second, dam construction in both basins does not impact $\mathrm{N}$ and $\mathrm{P}$ fluxes because these are mostly in the dissolved state (Figure 2). Rather, intensification of human activities (agricultural, urbanization, and industrialization) below the dam sites adds significant amounts of $\mathrm{N}$ and $\mathrm{P}$ to the delta-estuaries.

We present here an updated analysis of nutrient concentrations in both river basins based on more recent information (Figure 4). Although higher freshwater flux of the Yangtze has increased $\mathrm{N}$ and $\mathrm{P}$ fluxes by a factor of about three orders of magnitude than that of the Nile (Figures 2B,C and 3C), their concentrations do not have such large differences. The $\mathrm{N}$ concentration of the Nile, which was lower than the Yangtze from the 1970s-2000s, surpassed the Yangtze after the year 2000, while the P concentration has been constantly higher than the Yangtze. This is believed to be due to the extremely 
low freshwater flux below AHD reaching the coast (Figure 3A) with a weak dilution effect. On the other hand, the Yangtze is impacted by humans much more than the Nile in terms of population, urbanization, and fertilizer application (Figures $2 \mathrm{~B}, \mathrm{C}$ and $3 \mathrm{~B}$ ), and monsoon rain enhances the dilution of $\mathrm{N}$ and $\mathrm{P}$ concentrations in its estuary, although $\mathrm{P}$ remains lower.

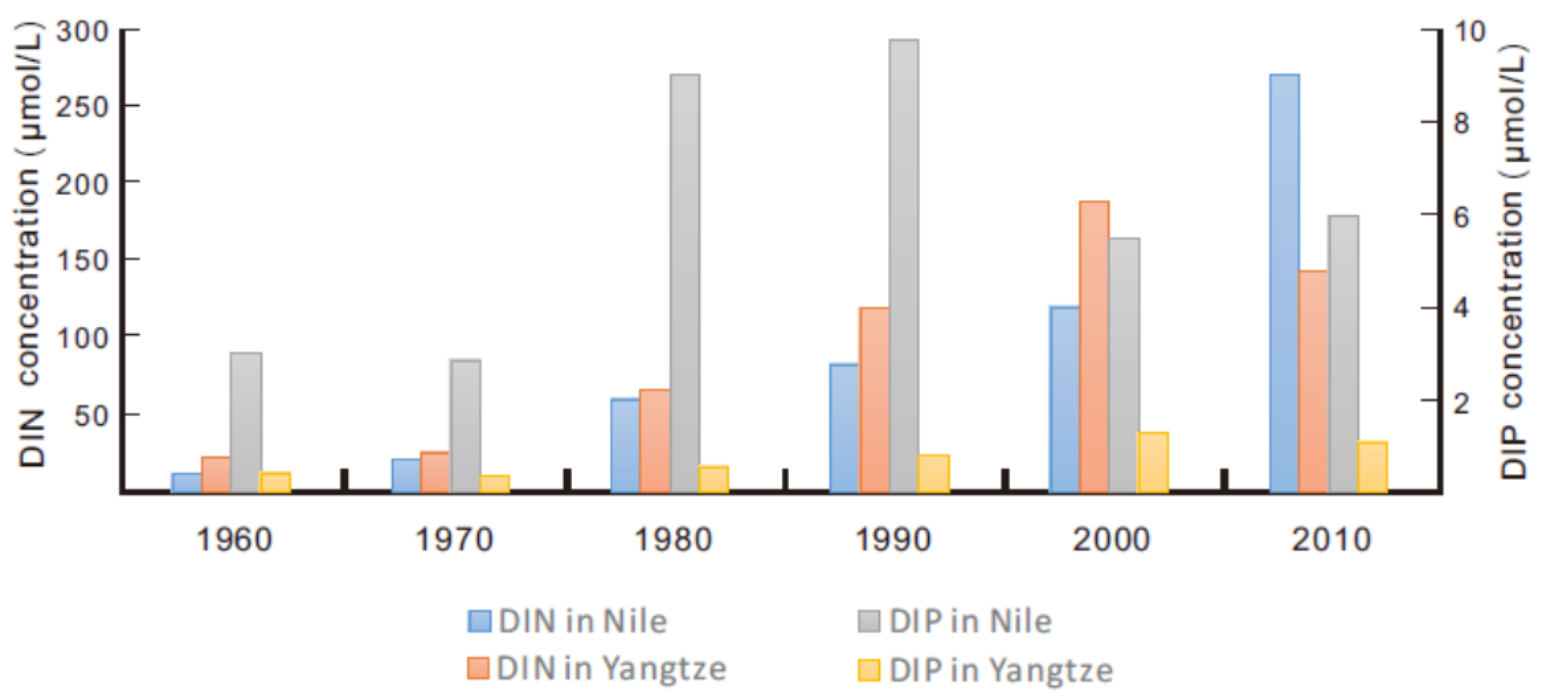

Figure 4. N- and P-concentration of the Yangtze estuary was re-calculated from [25], and that of the Nile estuary was recalculated from $[12,14,15]$.

Surprisingly, eutrophication and related algal blooms in the Nile delta-estuary, where nutrients are highly concentrated, seems to occur less than in the Yangtze. Although the monsoonal Yangtze delta-estuary has much higher hydrological self-adaptation than that of the Nile, HABs occur much more frequently than the Nile, due not only to the differences of geographical setting but also cultural factors, including the degree of economic development, industrialization, and urbanization. This comparative analysis concludes that there is no single damming process-response that can be copied from each other, and the restoration approaches of delta-estuaries need to follow shared knowledge and skills but local geographic uniqueness. Coastal management should adopt these differences through integrated approaches at river basin and deltaic scales and incorporated them into policy decisions and implementation.

Author Contributions: Conceptualization, Z.C. and H.X.; methodology, Z.C., H.X. and Y.W.; software, H.X. and Y.W.; validation, Z.C. and H.X.; formal analysis, Z.C., H.X., and Y.W.; investigation, Z.C., H.X.; resources, Z.C.; data curation, Z.C., H.X. and Y.W.; writing-original draft preparation, Z.C.; writing-review and editing, H.X. and Y.W.; visualization, H.X. and Y.W.; supervision, Z.C., project administration, Z.C.; funding acquisition, Z.C. All authors have read and agreed to the published version of the manuscript.

Funding: This study was supported by the China National Natural Foundation (Grant No. 41620104004) and the Fundamental Research Funds for Provincial Universities of Zhejiang (Grant No. SJLY2020004).

Institutional Review Board Statement: Not applicable.

Informed Consent Statement: Not applicable.

Data Availability Statement: Not applicable.

Acknowledgments: John Day provided comments on the paper.

Conflicts of Interest: The authors declare no conflict of interest. 


\section{References}

1. Day, J.W.; Ramachandran, R.; Giosan, L.; Syvitski, J.; Kemp, G.P. Delta Winners and Losers in the Anthropocene. Coasts Estuaries 2019, 149-165.

2. Wolanski, E.; Day, J.W.; Elliott, M.; Ramachandran, R. Coasts and Estuaries. In Future; Elsevier: Amsterdam, The Netherlands, 2019; p. 730.

3. Day, J.W.; Agboola, J.; Chen, Z.; D’Elia, C.; Forbes, D.L.; Giosan, L.; Kemp, P.; Kuenzer, C.; Lane, R.R.; Ramachandran, F.; et al. Approaches to defining deltaic sustainability in the 21st century. Estuar. Coast. Shelf Sci. 2016, 138, 275-291. [CrossRef]

4. Available online: http://www.stats.gov.cn/tjsj/ndsj/ (accessed on 2 March 2021).

5. Available online: https:// databank.worldbank.org/home.aspx (accessed on 2 March 2021).

6. Fielding, L.; Najman, Y.; Millar, Y.; Butterworth, P.; Ando, S.; Padoan, M.; Barfod, D.; Kneller, B. A detrital record of the Nile River and its catchment. J. Geol. Soc. 2016, 174, 301-317. [CrossRef]

7. Wang, Y.N.; Xu, H.; Li, M.T. Long-term changes in phytoplankton communities in China's Yangtze Estuary driven by altered riverine fluxes and rising sea surface temperature. Geomorphology 2021, 376, 1-9. [CrossRef]

8. Wang, B.; Xin, M.; Wei, Q.; Xie, L. A historical overview of coastal eutrophication in the China Seas. Mar. Pollut. Bull. 2018, 136, 394-400. [CrossRef] [PubMed]

9. Available online: http://www.mnr.gov.cn/sj/sjfw/hy/gbgg/zghyhjzlgb/ (accessed on 2 March 2021).

10. Tang, H.J. Studies of Eutrophication Features and Eutrophication-HABs Relationship in the Changjiang Estuary and Its Adjacent Area during the Past 30 Years and Strategies on Controlling Eutrophication. Ph.D. Thesis, Ocean University of China, Qingdao, Shandong, China, 2009. (In Chinese with English Abstract).

11. An, Q.; Wu, Y.; Wang, J.; Li, Z. Assessment of dissolved heavy metal in the Yangtze River estuary and its adjacent sea. China Environ. Monit. Assess. 2010, 164, 173-187. [CrossRef] [PubMed]

12. Hamza, W. The Nile Estuary. In Estuaries; Springer: Berlin/Heidelberg, Germany, 2006; pp. 149-173.

13. Nixon, S.W. The artificial Nile. Am. Sci. 2004, 92, 158-165. [CrossRef]

14. Ludwig, W.; Dumont, E.; Meybeck, M.; Heussner, S. River discharges of water and nutrients to the Mediterranean and Black Sea: Major drivers for ecosystem changes during past and future decades? Prog. Oceanogr. 2009, 80, 199-217. [CrossRef]

15. Sayed, S.M.E.; Hegab, M.H.; Mola, H.R.A.; Mola, A.; Ahmed, N.M.; Goher, M.E. An integrated water quality assessment of Damietta and Rosetta branches (Nile River, Egypt) using chemical and biological indices. Environ. Monit. Assess. 2020, 192, 1-16. [CrossRef]

16. Dorgham, M.M. Eutrophication problem in Egypt. In Eutrophication: Causes, Consequences and Control; Ansari, A.A., Gill, S.S., Lanza, G.R., Rast, W., Eds.; Springer: Berlin/Heidelberg, Germany, 2011; pp. 171-194. [CrossRef]

17. Oczkowski, A.J.; Nixon, S.W. Increasing nutrient concentrations and the rise and fall of a coastal fishery: A review of data from the Nile Delta, Egypt. Estuar. Shelf Sci. 2008, 77, 309-319. [CrossRef]

18. El-Gamal, A.A. Sediment and Water Quality of the Nile Delta Estuaries. Nile Delta 2016, 347-378.

19. Oczkowski, A.J. Fertilizing the Land, Lagoons and Sea: A First Look at Human Impacts on the Nile Delta Fishery, Egypt. Ph.D. Thesis, University of Rhode Island, Kingston, RI, USA, 2009.

20. Chen, Z.; Li, J.F.; Shen, H.T. Yangtze River, China, historical analysis of discharge variability and sediment flux. Geomorphology 2001, 41, 77-91. [CrossRef]

21. Chen, Z.; Wang, Z.H.; Finlayson, L.B.; Chen, J.; Yin, D. Implications of flow control by the Three Gorges Dam on sediment and channel dynamics of the middle Yangtze (Changjiang) River, China. Geology 2010, 38, 1043-1046. [CrossRef]

22. Dai, Z.J.; Liu, J.T. Impacts of large dams on downstream fluvial sedimentation: An example of the Three Gorges Dam (TGD) on the Changjiang (Yangtze River). J. Hydrol. 2013, 480, 10-18. [CrossRef]

23. Bastiaanssen, W.G.M.; Van der Wal, T.; Visser, T.N.M. Diagnosis of regional evaporation by remote sensing to support irrigation performance assessment. Irrig. Drain. Syst. 1996, 10, 1-23. [CrossRef]

24. Xu, H.; Chen, Z.; Finlayson, B.; Webber, M.; Wu, X.D.; Li, M.T.; Chen, J.; Wei, T.T.; Barnett, J.; Wang, M. Assessing dissolved inorganic nitrogen flux in the Yangtze River, China: Sources and scenarios. Glob. Planet. Chang. 2013, 106, 84-89. [CrossRef]

25. CWRCMWR (Changjiang Water Resource Commission of the Minstry of Water Resource). Changjiang Water and Sediment Bulletin (Internal Report); Yangtze Press: Wuhan, China, 2016. (In Chinese)

26. Li, M.T.; Xu, K.Q.; Watanabe, M.; Chen, Z.Y. Long-term variations in dissolved silicate, nitrogen, and phosphorus flux from the Yangtze River into the East China Sea and impacts on estuarine ecosystem. Estuar. Coast. Shelf Sci. 2007, 71, 3-12. [CrossRef]

27. Shi, Z. Tidal resuspension and transport processes of fine sediment within the river plume in the partially-mixed Changjiang River estuary, China: A personal perspective. Mar. Geol. 2010, 212, 133-151. [CrossRef]

28. Jiang, Z.; Liu, J.; Chen, J.; Chen, Q.; Yan, X.; Xuan, J.; Zeng, J. Responses of summer phytoplankton community to drastic environmental changes in the Changjiang (Yangtze River) estuary during the past 50 years. Water Res. 2014, 54, 1-11. [CrossRef]

29. Duan, S.W.; Liang, T.; Zhang, S.; Wang, L.J.; Zhang, X.M.; Chen, X.B. Seasonal changes in nitrogen and phosphorus transport in the lower Changjiang River before the construction of the Three Gorges Dam. Estuar. Coast. Shelf Sci. 2008, 79, 239-250. [CrossRef]

30. Zhou, M.; Shen, Z.; Yu, R. Responses of a coastal phytoplankton community to increased nutrient input from the Changjiang (Yangtze) River. Cont. Shelf Res. 2008, 28, 1483-1489. [CrossRef]

31. Chen, J.Y.; Pan, D.L.; Liu, M.L.; Mao, Z.H.; Zhu, Q.K.; Chen, N.H.; Zhang, X.Y.; Tao, B.Y. Relationships Between Long-Term Trend of Satellite-Derived Chlorophyll-a and Hypoxia Off the Changiiang Estuary. Estuaries Coasts 2017, 40, 1055-1065. [CrossRef] 
32. Wang, B.D. Cultural eutrophication in the Changjiang (Yangtze River) plume: History and perspective. Estuar. Coast. Shelf Sci. 2006, 69, 471-477. [CrossRef]

33. Li, X.; Bianchi, T.S.; Yang, Z.; Osterman, L.E.; Allison, M.A.; DiMarco, S.F.; Yang, G. Historical trends of hypoxia in Changjiang River estuary: Applications of chemical biomarkers and microfossils. J. Mar. Syst. 2011, 86, 57-68. [CrossRef] 